\title{
Recent advances in antimicrobial air filter
}

\author{
A.A.I.A.S. Komaladewi ${ }^{1}$, K. Khoiruddin ${ }^{2}$, I.W. Surata ${ }^{1}$, I.D.G.A. Subagia ${ }^{1}$, and I.G. Wenten ${ }^{2, *}$ \\ ${ }^{1}$ Mechanical Engineering Department, Udayana University, J1. Raya Kampus UNUD, Bukit Jimbaran, Kuta Selatan, Badung, Bali, \\ 803611, Indonesia \\ ${ }^{2}$ Chemical Engineering Department, Institut Teknologi Bandung, Jl. Ganesha 10, Bandung, 40132, Indonesia
}

\begin{abstract}
The worsening air quality has become an environmental issue since it has a serious effect on human health. This is generally attributed to airborne particles including various pathogens and others fine particles. Even though air filters show excellent removal efficiency towards pathogens, the captured microorganism can remain viable in the filter, grow, and re-suspended into an air stream resulting in a secondary source of pollutants. Considerable studies have been conducted to develop air filters which also have antibacterial properties for solving this issue. Results of several studies showed that air filters with antimicrobial activities have been successfully prepared by incorporating inorganic nanoparticles and natural plant extracts. With antibacterial properties, the air filters may be potentially used to control air quality, particularly for indoor spaces e.g. hospitals, by removing fine particles and inhibiting microorganism. In this paper, the recent development of antimicrobial air filter is reviewed. In addition, preparation and performance of developed antimicrobial filters are discussed. Prospects and challenges of antimicrobial air filter are also pointed out.
\end{abstract}

\section{Introduction}

As one of the environmental problems, air pollution can lead to serious effects on human health due to the worsening air quality. The deterioration of air quality is associated with various activities, such as industry, transportation, forest fire, and fuel usage [1]. Among the pollutant, airborne particles including fine particles and bioaerosols have gained increasing attention since they may be easily transported from one place to another. This is because the size of bioaerosols is ranging from submicron size $(<0.01 \mu \mathrm{m})$ to larger than $100 \mu \mathrm{m}[2,3]$. By considering the size, they can be suspended in the atmosphere and kinetically stable for a long time [4].

Several technologies have been developed for air purification, such as electrostatic precipitation, cold plasma, wet scrubbing, cyclonic air filtration (venturi), and physical filters (glass fibers, melt-blown fibers, spun-bonded fibers, and ceramic filters) [5-7]. Filtration is the most interesting technology for removal of airborne particles since it offers a simple operation, low energy requirement, and low operating and investment cost [8]. The features of physical air filtration lead to the increasing publications in this field. As shown in Fig. 1, numerous studies on the air filtration have been reported including membrane. Compared to conventional filter, membranes showed superior filtration efficiency since they are able to perform a molecular filtration. Membranes allow the passes of clean air, yet rejects fine particles. However, the airborne microorganism may accumulate on air filters which can become a secondary bioaerosols polluting source if the filters are not appropriately handled [9]. Therefore, antimicrobial or antibacterial air filters are urgently required.

Some previous review papers related to antimicrobial air filtration and nanofibers membranes air filter can be found $[8,10]$. Therefore, this review will be a complement of those papers. This paper reviews the recent development of antimicrobial air filter, including preparation and performance of antimicrobial filters, prospects, and challenges.

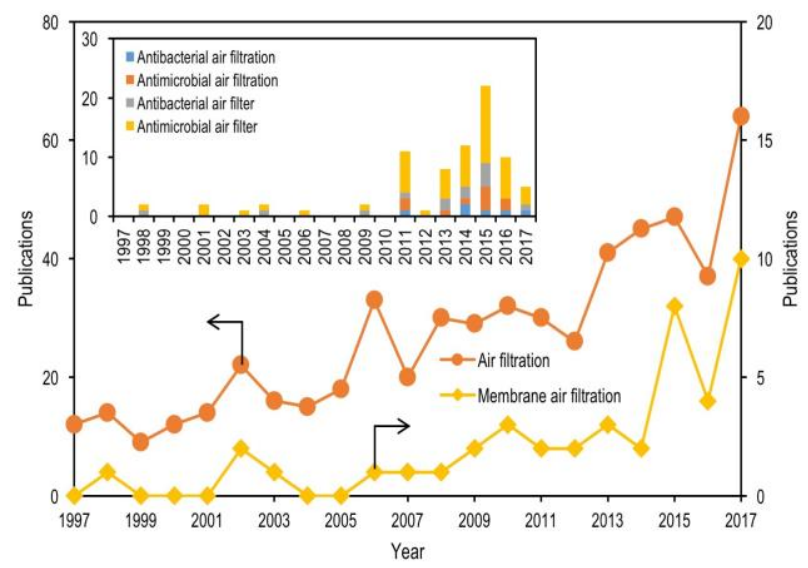

Fig. 1. Number of publications related to air filtration (indexed by Scopus; Query: TITLE(terms)).

\footnotetext{
* Corresponding author: igw@che.itb.ac.id
} 


\section{Air filtration}

In air filtration, a filter made from various materials such as glass fiber, polymer, or carbon is used. There are several types of air filter, such as non-woven fiber filter, nanofiber membrane, and porous polymeric membrane. According to EN1822 standard, high efficiency filters are divided into $\mathrm{H}$ or high efficiency particulate air (HEPA) and U or ultra-low particulate air (ULPA) [11]. HEPA is able to remove $99.97 \%$ of $0.3 \mu \mathrm{m}$ particles while ULPA removes at least $99.999 \%$ of $0.1 \mu \mathrm{m}$ particles.

In nanofiber membrane or other non-woven fiber filter, particulate removal may take place according to several mechanisms (Fig. 2) namely straining or sieving, interception, impaction, and Brownian diffusion [12]. For a porous membrane, the particle removal during air filtration is mainly due to size exclusion. Pressure drop at various face velocity of various air filters are depicted in Figure 3. As shown in Figure 3, symmetric PP membrane showed a relatively high permeability at lower pressure drop [13]. This is because porous hollow fiber membrane generally has thinner selective layer with lower pore size which provides both high permeability and separation ability.

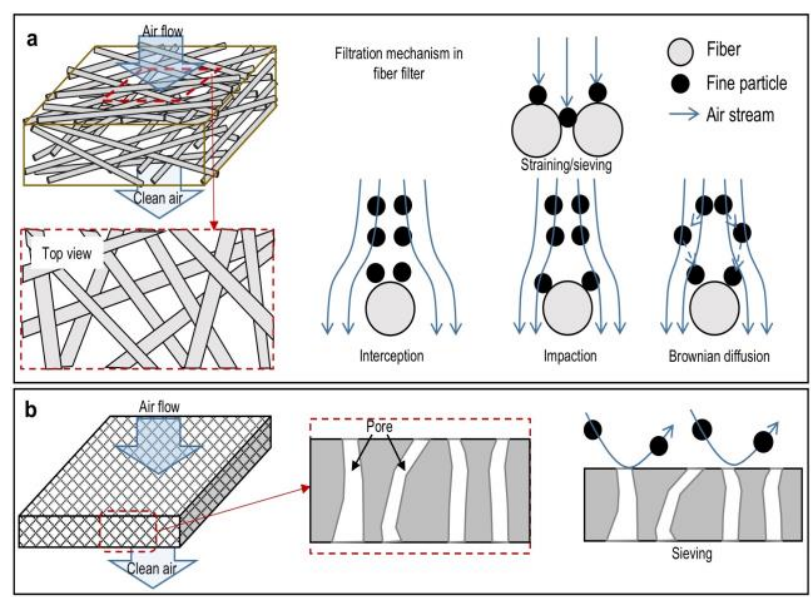

Fig. 2. Mechanism of fine particle removal from air in (a) fiber, nanofiber filter, or nanofiber membrane, (b) porous membrane.

\section{Membrane air filter}

Nowadays, membrane technology has played an important role in various industrial processes [14-19]. A rapid increase in membrane applications was driven by the advantages offered by this technology. Generally, membrane has a relatively low cost, requires less energy consumption, and needs a smaller foot print. In addition, the ability to perform a molecular level of filtration made membrane has high separation efficiency, including in air purification application. In air filtration, membrane usually consists of porous material or non-woven nanofiber which captures and retains particles throughout its depth or thickness (see Fig. 2). The latest membrane is also called as a nanofiber membrane.
Nanofiber membrane usually has a fiber diameter of less than $0.1 \mu \mathrm{m}$. Nanofiber membrane can be prepared by melt fibrillation, gas jet, and self-assembly methods are [20-22]. Due to several limitation of those methods, researcher are now employing electro-spinning [23-25]. Nanofiber membrane exhibited several advantages, such as high density of pores, high packing density, high permeability, easy for surface functionalization, and good mechanical property [26,27].

Modification on nanofiber membrane have been conducted by several works using various types of modifier and materials (Table 1). To improve the separation property, nanofiber membrane has been modified, for example by introducing nanonets. Liu et al. [28] demonstrated that the nanonets could improve the mechanical strength as well as the particle removal rate of the nanofiber membrane by providing an additional naofilter (99.9995\%). Zhang et al. [29] reported that the nanonets also reduce the pressure drop $\left(\begin{array}{lll}60 & \mathrm{~Pa}\end{array}\right)$. Modification was also conducted by introducing porous nanobead on the fiber [30]. It was reported that the beads could improve the filtration efficiency.

\section{Antimicrobial air filter}

An air stream may contain bioaerosols which can cause various health problems to human if they are inhaled. Bioaerosols consist of bacteria, viruses, fungi, yeast, fungal spores, and pollen and their fragments (including various antigens) [31]. The risk of health problem is much greater for indoor air circulation since people are now spending more time in indoor activities. Various antimicrobial technologies such as ultraviolet irradiation and heating [10,32], air ions emission [33], ozone [34], etc., are used to remove bioaerosols. Recently, air filters are widely used to capture bioaerosols due to their simplicity and low cost [35]. Even though an air filter is able to capture bioaerosols, they can remain viable in the filter, grow, and resuspended into an air stream thus possessing a risk to become a secondary source of pollutant [36]. Therefore, numerous studies have been devoted to prepare air filters which have antimicrobial properties by introducing antimicrobial agents (Table 2).

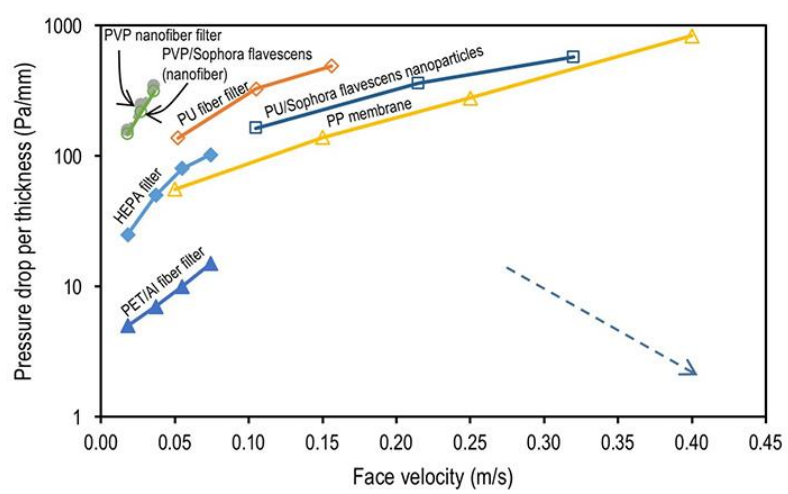

Fig. 3. Pressure drop vs face velocity of various filter during air filtration (Note: data from refs. [35-39]; symmetric PP membrane) 
Table 1. Material, modifier, and performance of nanofiber membranes.

\begin{tabular}{|c|c|c|c|c|c|c|}
\hline Material & Modifier & $\begin{array}{l}\text { Particulate size } \\
\qquad(\mu \mathrm{m})^{*}\end{array}$ & $\begin{array}{c}\text { Flow rate } \\
(\mathrm{L} / \mathrm{min})\end{array}$ & $\begin{array}{c}\text { Filtration } \\
\text { efficiency }(\%)\end{array}$ & $\begin{array}{c}\text { Pressure drop } \\
\text { (Pa) }\end{array}$ & Ref. \\
\hline PA-56 & Nanofiber/nets & $0.3-0.5$ & 30 & 99.996 & 100 & {$[37]$} \\
\hline PAN & Silica Nanofibrous $\mathrm{SiO}_{2}$ & $0.3-0.5$ & 85 & 99.99 & 117 & {$[38]$} \\
\hline PEI & Nanoparticles Boehmite & 0.3 & 32 & 95 & 75 & [33] \\
\hline PEI & Nanoparticles $\mathrm{BaTiO}_{3}$ & 0.3 & 32 & 85 & 58 & {$[33]$} \\
\hline PI & Carbon woven & $0.3-2.5$ & 40 & 93 & 462.6 & [34] \\
\hline PSF & $\mathrm{TiO}_{2}$ & $0.3-0.5$ & 30 & 99.9 & 40 & {$[31]$} \\
\hline
\end{tabular}

PA - polyamide; PAN - polyacrylonitrile; PEI - Polyetherimide; PI - polyimide; PSF - polysulfone; * particles used for filter test.

Table 2. Material, preparation method, and performances of antimicrobial air filter.

\begin{tabular}{|c|c|c|c|c|c|}
\hline Filter type & Filter material & Antimicrobial agent & $\begin{array}{c}\text { Preparation } \\
\text { method }\end{array}$ & Remarks & Ref. \\
\hline $\begin{array}{l}\text { High efficiency air } \\
\text { filter media } \\
\text { (HEPA) }\end{array}$ & Fiberglass & $\begin{array}{l}\varepsilon \text {-Polylysine and } \\
\text { Natamycin }\end{array}$ & Dip-coating & $\begin{array}{c}\text { Staphylococcus aureus: } \\
\text { filtration efficiency }=99.998 \% \\
\text { antibacterial efficiency }= \\
99.996 \%\end{array}$ & [40] \\
\hline Fiber filter & Polyurethane & $\mathrm{Ag} / \mathrm{CNTs}$ & $\begin{array}{l}\text { Nebulization / } \\
\text { aerosol process }\end{array}$ & $\begin{array}{c}\text { E. Coli filtration efficiency }= \\
\sim 95 \% ; \text { relative microbial } \\
\text { viability }<0.2 \%\end{array}$ & [38] \\
\hline Fiber filter & Polyurethane & $\begin{array}{l}\text { Euscaphis japonica } \\
\text { methanolic extract } \\
\text { powder }\end{array}$ & $\begin{array}{l}\text { Nebulization / } \\
\text { aerosol process }\end{array}$ & $\begin{array}{c}M . \text { luteus: antimicrobial } \\
\text { efficiency }=\sim 82 \% \text {; filtration } \\
\text { efficiency }=\sim 95 \%\end{array}$ & [41] \\
\hline Fiber filter & $\begin{array}{c}\text { Polyethylene } \\
\text { terephthalate } \\
\text { (fiber diameter }= \\
1.5 \mu \mathrm{m})\end{array}$ & Propolis & $\begin{array}{l}\text { Nebulization / } \\
\text { aerosol process }\end{array}$ & $\begin{array}{c}\text { Penetration levels of } \\
\text { bioaerosols }=1.4-2.0 \% ; \\
\text { Inactivation rates }=54.4-75.5 \%\end{array}$ & [42] \\
\hline Fiber filter & Polyurethane & $\begin{array}{l}\text { Nanoparticles of } \\
\text { Sophora flavescens } \\
\text { ethanolic extract }\end{array}$ & Electro-spraying & $\begin{array}{l}\text { S. epidermidis: Relative } \\
\text { microbial viability }=\sim 0 \% \text {; }\end{array}$ & [43] \\
\hline Polyester air filter & Polyester & $\begin{array}{l}\text { PMA- capped silver } \\
\text { nanoparticles }\end{array}$ & $\begin{array}{l}\text { Layer-by-layer } \\
\text { coating technique }\end{array}$ & $\begin{array}{c}\text { S. aureus: reduction rate }= \\
92.2 \%\end{array}$ & [44] \\
\hline $\begin{array}{l}\text { Nanofiber filter } \\
\text { (Fiber diameter }= \\
\text { from } 300-400 \mathrm{~nm} \text { ) }\end{array}$ & $\begin{array}{c}\text { Sericin/Poly Vinyl } \\
\text { Alcohol } \\
\text { (PVA)/Clay } \\
\end{array}$ & Sericin & Electro-spinning & $\begin{array}{c}\text { E. Coli: Antibacterial activity }= \\
98.3 \%\end{array}$ & {$[45]$} \\
\hline Fiber filter & $\begin{array}{l}\text { Polyethylene } \\
\text { terephthalate } \\
\text { (PET) }\end{array}$ & $\begin{array}{l}\text { Grapefruit seed } \\
\text { extract }(G S E)\end{array}$ & Spray coating & $\begin{aligned} \text { S. aureus: } & \text { inactivation rate }= \\
& >98 \%\end{aligned}$ & [46] \\
\hline
\end{tabular}

Performances of air filter with inorganic antimicrobial agents have been reported by several studies (Table 2). Recently, researcher started to use natural products extract as antimicrobial agents. In addition to its high antimicrobial activity, natural products are considered as less toxic than inorganic antimicrobial agent. Hwang et al. [41] investigated the preparation antimicrobial filter by employing nebulization or aerosol process for coating a filter with Euscaphis japonica nanoparticles. They found that pressure drop and antimicrobial activities of the filter were function of deposition time. Even though, the
Euscaphis japonica showed lower toxicity than the carcinogen, further study is still required to assure that it is harmless to human health. Han et al. [46] compared antimicrobial activity of two natural products, i.e. GSE and propolis deposited on PET air filter. The natural products were deposited using a spray gun. At the deposition weight of 5000-8000 $\mu \mathrm{g} / \mathrm{cm}^{2}$, GSE displayed a better microbial inhibition rate of $\sim 98 \%$ than propolis $(\sim 75 \%)$. They suggested that the higher inhibition rate was related to a higher wettability of the deposited GSE showed by a water contact angle of $<20^{\circ}$. In addition, GSE has lower cost than propolis. Lee et al. [13] used 
Gingko Biloba L. and Sumac (Rhus Javanica L.) extracts as antimicrobial agents. Those extracts were used for coating polypropylene filter. The prepared air filter showed an excellent antimicrobial activity, especially for new influenza (H1N1) virus and A/PuertoRico/8/34 $(\mathrm{A} / \mathrm{PR} / 8)$ virus $(<99.9999 \%)$.

Even though those reported natural product extracts displayed high antibacterial activities, durability of coated natural products should also be taken into consideration, especially for application in a real condition. For instance, the antibacterial activity may be affected by temperature [47] or degradation due to natural oxidation process [48]. Combining natural extracts with inorganic material may solve the problem of durability. For example, Purwar et al. [45] fabricated antimicrobial mask made of Sericin/Poly Vinyl Alcohol (PVA)/Clay (Cloisite 30B) via an electro-spinning method. The electro-spun fibers had 300-400 nm diameter. The filter with $0.75 \%$ showed a greater filtration efficiency of particulate matter $(1-10 \mu \mathrm{m})$ of concentration $0.725 \mathrm{gm} / \mathrm{m}^{3} / \mathrm{s}$ with an excellent antimicrobial activity. Hwan et al. [49] synthesized multi-walled carbon nanotubes (MWCNTs) which was modified by coating natural product (NP). The NP/MWCNTs was prepared by using an electro-spray system. The NP/MWCNTs were then used as antimicrobial agents. The microbial inactivation rate was $95 \%$.

To improve an antibacterial activity of an air filter, researchers also used additional technique and combined with an air filter into a combined system. For instance, Sim et al. [50] studied the performance of combined air filter (coated with Sophora flavescens) and electrostatic activation. The electrostatic activation may help to increase electrostatic interaction between the filter and the microorganism. Hwang et al. [51] determined the effect of surrounding electric field (EF) on antimicrobial air filters performance. The antimicrobial filter was coated by natural products nanoparticles. Captured bacteria were increased when EF was applied. Moreover, the inactivation rate was also improved. Zhang et al. [29] investigated air filtration assisted by a microwave for bioaerosol removal. The microwave assisted air filtration displayed an effective disinfection against $E$. coli. However, a less effective disinfection was observed on $B$. subtilis endospores. Bioaerosol inactivation may also be performed by using air ions, as reported by Hyun et al. [52]. They used air ions during the filtration of bacteriophage MS2 bioaerosols. Air ions were generated by carbon-fiber ionizer. Air ions were used to charge bioaerosols so the filtration efficiency could be enhanced.

\section{Preparation of antimicrobial air filter}

There are various methods which have been reported for preparing antimicrobial air filter. In general, the methods can be classified into modification of available air filter and direct processing (Fig. 4). In the first type, antimicrobial agents are deposited or coated on air filter surface, while in the second one, the agents can be directly blended with filter material prior to filter preparation. The antimicrobial agents may be inorganic nanoparticles or natural products extracts as previously explained. Some polymeric materials are naturally antimicrobials [53] thus allowing direct processing of the material into an air filter.

Depositing nanoparticle of antimicrobial agent onto membrane surface may be conducted by dip-coating [13,36,40,54-56], layer-by-layer coating [44], spray coating [46], nebulization process (aerosol process) $[34,37,38,42,48]$, and electro-spraying $[4,43,49]$. Illustrations of the methods are shown in Fig. 5. Even though the nanoparticles successfully improved the antimicrobial activity of the air filter, the pressure drop of the filtration was increased. It might be happened due to the increasing mass transfer resistance. Therefore, additive blending or direct processing of antimicrobial agent into an air filter is preferable. The antimicrobial agent can be blended into polymer solution and then made into nanofiber membrane via electro-spinning $[35,45]$ or into flat sheet membrane via solution casting method [57].

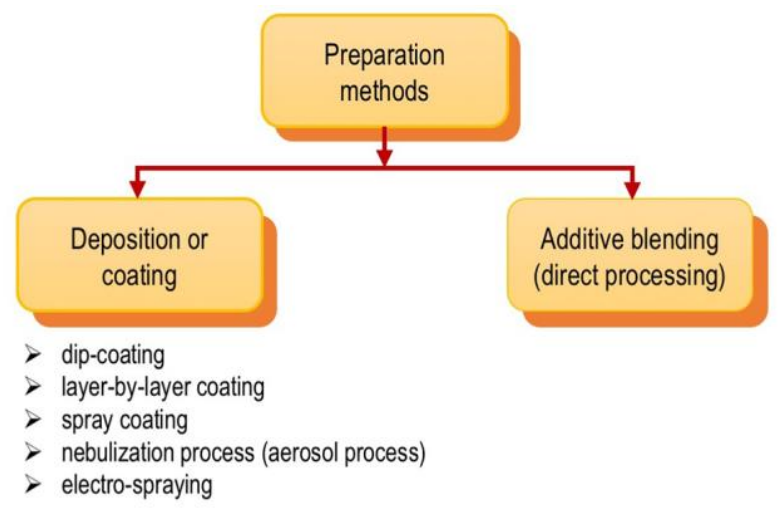

Fig. 4. Preparation methods of antimicrobial air filter.

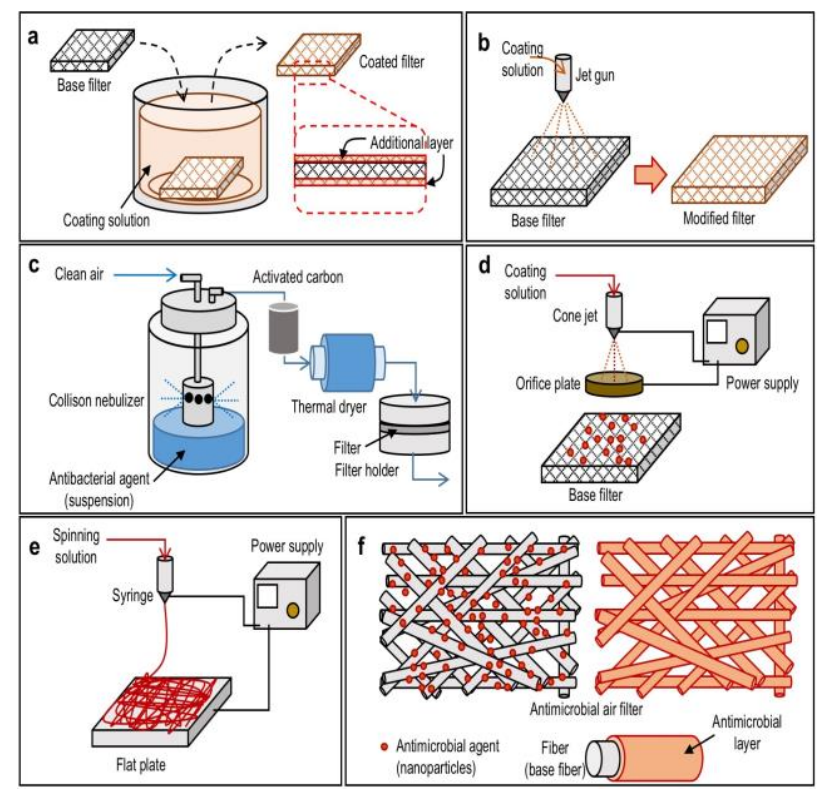

Fig. 5. Illustrations of (a) dip-coating, (b) spray-coating, (c) nebulization process, (d) electro-spraying, (e) electro-spinning, and (f) deposited and coated antimicrobial agent. 


\section{Pathogen removal during air filtration}

Mechanisms of air filtration in fiber or nanofiber filter and membrane have been discussed in the previous section. During the air filtration, bioaerosols are also captured by the filters. In antimicrobial air filter, the growth of captured microbes is inhibited by antimicrobial agents. The inhibition mechanism highly depends on the type of antimicrobial agent.

Antimicrobial agent can induce cell destruction leading to cell death. For example, Ag nanoparticles may damage the cell membrane and changes the metabolic system [58,59]. Similar to Ag, carbon nanotube (CNT) also induces cell membrane damage followed by cell death [41]. Antibacterial agents from natural product extract may contain flavonoids which have antibacterial activities due to several mechanisms, such as inhibition of DNA gyrase, reduction of cell membrane fluidity, the change of cell permeability, and the damage of cell membrane function [13]. However, considering their effect to organic cell, the antimicrobial agent should be non-toxic for avoiding health issues to human.

\section{Prospect and challenges}

Air filtrations is an attractive option for solving the worsening air quality contaminated by airborne particles. Airborne particles including fine particles and bioaerosols may pose an adverse impact on human health. Even though an air filter can effectively capture the particles, the accumulation of captured bioaerosols may become a secondary polluting source. Therefore, an air filter which also has antimicrobial activities are also needed. The antimicrobial air filter allows the separation of bioaerosols as well as microbial growth inhibition due to antimicrobial activity. To endow an air filter with antimicrobial activity, nanoparticles including inorganic and natural extract product may be used and coated to the filter surface. It has been reported in several studies that natural product extract exhibited an excellent antimicrobial activity, less toxic than inorganic materials, low cost, abundant, and also environmental friendly. However, the durability of the antimicrobial agent made by natural product extract needs to be investigated, especially for a long-term test in a real condition. Some studies also indicated that natural product extracts are sensitive to environmental conditions (temperature, humidity, etc.). Most antimicrobial agents or nanoparticles have physically adhered to the fiber surface thus the antimicrobial filter had poor durability. In addition, the antimicrobial agents may be covered by captured particles thus reducing the functionality. Therefore, for future development, the said problems should be taken into consideration.

\section{References}

1. A. Fugiel, D. Burchart-Korol, K. Czaplicka-Kolarz, A. Smoliński, J. Clean. Prod., 143, 159 (2017).

2. G.J.D. Smith, D. Vijaykrishna, J. Bahl, S.J. Lycett, M. Worobey, O.G. Pybus, S.K. Ma, C.L. Cheung,
J. Raghwani, S. Bhatt, J.S.M. Peiris, Y. Guan, A. Rambaut, Nature, 459, 1122 (2009).

3. C.B. Beggs, Indoor Built Environ., 12, 9 (2003).

4. J.S. Kang, H. Kim, J. Choi, H. Yi, S.C. Seo, G.-N. Bae, J.H. Jung, Aerosol Air Qual. Res., 16, 2059 (2016).

5. J.-P. Brincat, D. Sardella, A. Muscat, S. Decelis, J.N. Grima, V. Valdramidis, R. Gatt, Trends Food Sci. Technol., 50, 175 (2016).

6. A. Joubert, J.-C. Laborde, L. Bouilloux, S Chazelet, D. Thomas, Chem. Eng. J., 166, 616 (2011).

7. C.-H. Hung, W.W.-F. Leung, Sep. Purif. Technol., 79, 34 (2011).

8. Z. Miaomiao, H. Jingquan, W. Fang, S. Wei, X. Ranhua, Z. Qilu, P. Hui, Y. Yong, S.S. Keshari, Z. Feng, H. Chaobo, Macromol. Mater. Eng., 302, 1600353 (2017).

9. S.A. Batterman, H. Burge, HVAC\&R Res., 1, 61 (1995).

10. G.-N. Bae, J.H. Jung, J. Nanosci. Nanotechnol., 16, 4487 (2016).

11. M.R. Noor, K. Kowal, P. Tiernan, T. Soulimane, S.A.M. Tofail, Antimicrobial air filters, in: Electr. Act. Mater. Med. Devices, Chemical and Environmental Sciences Department, University of Limerick, Ireland (2016), pp. 349-364.

12. K.-T. Park, J. Hwang, Carbon N. Y., 75, 401 (2014).

13. K.M. Lee, B.H. Lee, C.J. Park, Appl. Mech. Mater., 284-287, 1601 (2013).

14. I.G. Wenten, P.T. Dharmawijaya, P.T.P. Aryanti, R.R. Mukti, Khoiruddin, RSC Adv., 7, 29520 (2017).

15. I.G. Wenten, K. Khoiruddin, A.N. Hakim, N.F. Himma, Chapter 11 - The Bubble Gas Transport Method - Membrane Characterization, in: Elsevier, (2017), pp. 199-218.

16. M. Sianipar, S.H. Kim, Khoiruddin, F. Iskandar, I.G. Wenten, RSC Adv., 7, 51175 (2017).

17. D. Mangindaan, K. Khoiruddin, I.G. Wenten, Trends Food Sci. Technol., 71, 36 (2018).

18. Khoiruddin, D. Ariono, Subagjo, I.G. Wenten, J. Appl. Polym. Sci., 134, 45540 (2017).

19. R. Desiriani, M.T.A.P. Kresnowati, I.G. Wenten, Int. J. Technol., 8, 1393 (2017).

20. W. Daan, S.U. S., Angew. Chemie Int. Ed., 43, 2480 (2004)

21. S. Ramakrishna, K. Fujihara, W.-E. Teo, T. Yong, Z. Ma, R. Ramaseshan, Mater. Today, 9, 40 (2006).

22. A.A. Tseng, A. Notargiacomo, T.P. Chen, J. Vac. Sci. Technol. B Microelectron. Nanom. Struct. Process. Meas. Phenom., 23, 877 (2005).

23. Z. Miaomiao, H. Jingquan, W. Fang, S. Wei, X. Ranhua, Z. Qilu, P. Hui, Y. Yong, S.S. Keshari, Z. Feng, H. Chaobo, Macromol. Mater. Eng., 302, 
1600353 (2016).

24. W.S. Khan, R. Asmatulu, M. Ceylan, A. Jabbarnia, Fibers Polym., 14, 1235 (2013).

25. P. Gibson, H. Schreuder-Gibson, D. Rivin, Colloids Surfaces A Physicochem. Eng. Asp., 187-188, 469 (2001).

26. Z.-M. Huang, Y.-Z. Zhang, M. Kotaki, S. Ramakrishna, Compos. Sci. Technol., 63, 2223 (2003).

27. R. Balamurugan, S. Sundarrajan, S. Ramakrishna, Membr. , 1, (2011).

28. B. Liu, S. Zhang, X. Wang, J. Yu, B. Ding, J. Colloid Interface Sci., 457, 203 (2015).

29. Q. Zhang, B. Damit, J. Welch, H. Park, C.-Y. Wu, W. Sigmund, J. Aerosol Sci., 41, 880 (2010).

30. Z. Wang, C. Zhao, Z. Pan, J. Colloid Interface Sci., 441, 121 (2015).

31. N. Kalogerakis, D. Paschali, V. Lekaditis, A. Pantidou, K. Eleftheriadis, M. Lazaridis, J. Aerosol Sci., 36, 751 (2005).

32. C.-Y. Lin, C.-S. Li, Aerosol Sci. Technol., 36, 474 (2002).

33. H. R., A. I., P. O., G. S., Indoor Air, 18, 106 (2008).

34. G.B. Hwang, J.E. Lee, C.W. Nho, B.U. Lee, S.J. Lee, J.H. Jung, G.-N. Bae, Sci. Total Environ., 421-422, 273 (2012).

35. J. Choi, B.J. Yang, G.-N. Bae, J.H. Jung, ACS Appl. Mater. Interfaces, 7, 25313 (2015).

36. D.Y. Choi, K.J. Heo, J. Kang, E.J. An, S.-H. Jung, B.U. Lee, H.M. Lee, J.H. Jung, J. Hazard. Mater., 351, 29 (2018).

37. J.H. Jung, G.B. Hwang, S.Y. Park, J.E. Lee, C.W. Nho, B.U. Lee, G.-N. Bae, Aerosol Sci. Technol., 45, 1510 (2011).

38. J.H. Jung, G.B. Hwang, J.E. Lee, G.N. Bae, Langmuir, 27, 10256 (2011).

39. P. Bulejko, M. Dohnal, J. Pospíšil, T. Svěrák, Sep. Purif. Technol., 197, 122 (2018).

40. J. Yang, Z. Wang, J. Wu, L. Hao, T. Tian, S. Lin, Adv. Mater. Res., 152-153, 1519 (2011).
41. G.B. Hwang, K.J. Heo, J.H. Yun, J.E. Lee, H.J. Lee, C.W. Nho, G.-N. Bae, J.H. Jung, PLoS One, 10, (2015).

42. C.G. Woo, J.-S. Kang, H.-J. Kim, Y.-J. Kim, B. Han, Aerosol Sci. Technol., 49, 611 (2015).

43. J.H. Jung, J.E. Lee, G.-N. Bae, J. Aerosol Sci., 57, 185 (2013).

44. E. Detsri, K. Kamhom, D. Ruen-ngam, J. Exp. Nanosci., 11, 930 (2016).

45. R. Purwar, K. Sai Goutham, C.M. Srivastava, Fibers Polym., 17, 1206 (2016).

46. B. Han, J.-S. Kang, H.-J. Kim, C.-G. Woo, Y.-J. Kim, Aerosol Air Qual. Res., 15, 1035 (2015).

47. K.M. Sim, H.J. Lee, C.W. Nho, G.-N. Bae, J.H. Jung, Aerosol Sci. Technol., 48, 324 (2014).

48. E.-S. Chong, G.B. Hwang, C.W. Nho, B.M. Kwon, J.E. Lee, S. Seo, G.-N. Bae, J.H. Jung, Sci. Total Environ., 444, 110 (2013).

49. G.B. Hwan, K.M. Sim, G.-N. Bae, J.H. Jung, J. Aerosol Sci., 86, 44 (2015).

50. K.M. Sim, H.-S. Park, G.-N. Bae, J.H. Jung, Sci. Total Environ., 533, 266 (2015).

51. G.B. Hwang, H.-S. Park, G.-N. Bae, J.H. Jung, Aerosol Air Qual. Res., 14, 1028 (2014).

52. J. Hyun, S.-G. Lee, J. Hwan, J. Aerosol Sci., 107, 31 (2017).

53. P.T.P. Aryanti, M. Sianipar, M. Zunita, I.G. Wenten, Membr. Water Treat., 8, 463 (2017).

54. N.F. Himma, A.K. Wardani, I.G. Wenten, Polym. Plast. Technol. Eng., 56, 184 (2017).

55. N.F. Himma, A.K. Wardani, I.G. Wenten, Mater. Res. Express, 4, 054001 (2017).

56. C. Thunyasirinon, P. Sribenjalux, S. Supothina, P. Chuaybamroon, Aerosol Air Qual. Res., 15, 600 (2015).

57. L. Tamayo, M. Azócar, M. Kogan, A. Riveros, M. Páez, Mater. Sci. Eng. C, 69, 1391 (2016).

58. V.K. Sharma, R.A. Yngard, Y. Lin, Adv. Colloid Interface Sci., 145, 83 (2009).

59. J.P. Ruparelia, A.K. Chatterjee, S.P. Duttagupta, S. Mukherji, Acta Biomater., 4, 707 (2008). 